\title{
Małżeństwo i rozwód w Kościele prawosławnym - aspekt prawno-kanoniczny
}

Ujęcie istoty małżeństwa kanonicznego w Kościele łacińskim i w Kościele posiada pewne podobieństwa i różnice. Wymagania stawiane nupturientom, przeszkody do zawarcia małżeństwa, forma jego zawarcia w Kościele prawosławnym jest tematem pomijanym przez specjalistów tegoż Kościoła. Istnieją obszerne publikacje dotyczące teologii czy liturgii tego sakramentu, natomiast opracowania na temat kwestii prawnych małżeństwa są nieliczne i trudno dostępne. Być może jest to spowodowane brakiem kodyfikacji kanonicznej dotyczącej tego sakramentu, a to jest przyczyną niemożliwości dotarcia do jego źródeł. Normy stosowane odnośnie do tej materii pochodzą z ustawodawstwa starożytnych soborów ekumenicznych, lokalnych i prowincjalnych synodów, nauki ojców Kościoła. Wiele z nich dawno straciło na aktualności, często są sprzeczne ze sobą. W chwili obecnej trwają prace nad usystematyzowaniem i uwspółcześnieniem prawa prawosławnego odnośnie do małżeństwa.

\section{Warunki zawarcia małżeństwa}

Prawo małżeńskie ma za zadanie stać na straży moralnej czystości, świętości i ideału małżeństwa. Dlatego różne reguły i ograniczenia, które były i ciągle są proponowane chrześcijanom w odniesieniu do tego sakramentu, 
są po to, by strzec i zachować jego fundamentalne znaczenie w konkretnych warunkach ludzkiego życia. To nie są zasady dla samych zasad, ich celem jest ochrona zarówno boskiej, jak i ludzkiej rzeczywistości małżeństwa, a w konsekwencji zachowanie człowieka od upadku ${ }^{1}$.

Nowy Testament zawiera tylko ogólne zasady odnoszące się do małżeństwa, ich sprecyzowanie leży w gestii Kościoła. Nie ulega wątpliwości, że prawosławie nie uchybiając w niczym zasadom kodeksu łacińskiego, zaprowadza własne prawo małżeńskie, a szczególnie własny katalog przeszkód małżeńskich, nie mówiąc już o własnej formie zawarcia sakramentu małżeństwa. W tego rodzaju postanowieniach legislacyjnych są zgodni z normami prawa naturalnego, prawa Bożego pozytywnego, a także z podstawowymi zasadami chrześcijańskiej moralności².

Jak dotąd, Kościół prawosławny nie posiada jednolicie skodyfikowanego prawa małżeńskiego. Wszelkie wymogi i ograniczenia zawarte są w tzw. Kanonach, które obowiązują cały Kościół prawosławny. O sprawach małżeństwa mówią następujące Kanony ${ }^{3}$ :

1. apostolskie: $5,15,19,26,48,51,61$;

2. Soborów Powszechnych: Czwartego: 6, 14-16, 27; Szóstego: 3, 4, 6, 12, 13, 26, 30, 40, 47, 48, 53, 54, 72, 87, 92, 93; Siódmego: 22;

3. Soborów lokalnych: w Ancyrze (314 r.): 10-12, 16, 17, 19, 20, 26; Neocezarejskiego (314 r.): 1, 4, 9, 10, 14, 17; Laodycejskiego (364 r.): 1, 10, 21, 31, 52, 54; Kartagińskiego (419 r.): 4, 6, 21, 25 , 102 ;

4. ojców Kościoła: św. Dionizego Aleksandryjskiego (+246 r.): 2, 3; św. Bazylego Wielkiego (+379 r.): 4, 6, 9, 12, 18, 22, 27, 30, 33-42, 48-50, 53, 58, 67-69, 77-78, 87, 88; św. Tymoteusza Aleksandryjskiego (+385 r.): 5, 11, 13, 15; bł. Teofana (+412 r.): 5 .

Wiele z tych starożytnych kanonów straciło już na aktualności. Obecnie Kościół prawosławny przygotowuje się do soboru, którego jednym z zadań będzie właściwa analiza i uwspółcześnienie tych tekstów kanonicznych. s. $56-57$.

I Por. J. Meyendorff, Matżeństwo w prawosławiu. Liturgia, teologia, życie, Lublin 1995,

2 Zob. E. Przekop, Prawosławie wobec władzy stanowienia własnego prawa matżeńskiego, „Ateneum Kapłańskie”, 1977, t. 89, z. 413, s. 337-348.

3 Por. S. Hrycuniak, Prawostawne pojmowanie matżeństwa, Białystok 1994, s. 88. 


\subsection{Formalności poprzedzające zawarcie małżeństwa}

Osoby, które zamierzają zawrzeć związek małżeński, powinny zgłosić się do proboszcza parafii przyszłego małżonka, którego obowiązuje miejsce stałego zamieszkania, by ten dokonał przewidzianych formalności, stwierdzających, iż nie ma przeszkód do zawarcia małżeństwa sakramentalnego. Każdy proboszcz jest zobowiązany do prowadzenia księgi „dochodzenia przedmałżeńskiego”, gdzie zapisuje imiona i nazwiska narzeczonych, wiek, przynależność wyznaniową, miejsce stałego zamieszkania, brak przeszkód wynikających z pokrewieństwa i powinowactwa. Powinien tam zaznaczyć także to, czy zawierają małżeństwo z własnej nieprzymuszonej wolí .

Narzeczeni mają obowiązek dostarczyć proboszczowi stosowne dokumenty: metrykę chrztu, odpis aktu małżeństwa zawartego w Urzędzie Stanu Cywilnego oraz świadectwo przedślubne od proboszcza parafii rodzimej, jeśli jedno z nich należy do innej parafii. Narzeczeni oraz dwóch świadków podpisują się w obecności proboszcza, potwierdzając w ten sposób aktualność i prawdziwość przedstawionych przez siebie danych. Ponadto w czasie badania przedślubnego proboszcz winien sprawdzić, czy narzeczeni znają podstawowe prawdy wiary i czy zdają sobie sprawę z podstawowych obowiązków wynikających z małżeństwa. Po badaniu przedślubnym mają być ogłoszone w świątyni parafialnej zapowiedzi w ciągu trzech najbliższych świąt lub niedziel celem upewnienia się, czy rzeczywiście nie ma przeszkód do zawarcia małżeństwa sakramentalnego w danym przypadku5 Jeżeli po ogłoszeniu zapowiedzi zostaną zgłoszone przeszkody do zawarcia małżeństwa, kapłan nie ma prawa wyrazić zgody na jego zawarcie. Wschodnie greckie Patriarchaty prawosławne nie znają zwyczaju ogłaszania zapowiedzi przedślubnych ${ }^{6}$.

Biskup diecezjalny ma prawo zwolnić od ogłoszenia zapowiedzi. Jeżeli w ciągu dwóch miesięcy od momentu ogłoszenia zapowiedzi nie zostanie zawarte małżeństwo, zapowiedzi powinny być ogłoszone ponownie.

Po pobłogosławieniu małżeństwa, kapłan ma obowiązek odnotować ten fakt w księgach metrykalnych w parafii, gdzie zostało zawarte małżeństwo ${ }^{7}$.

4 Por. tamże, s. 102.

5 Por. tamże, s. 103.

6 Por. tamże, s. 104.

7 Por. E. Przekop, Prawostawie wobec władzy stanowienia własnego prawa matżeńskiego, dz. cyt., s. 340 . 


\subsection{Klasyfikacja przeszkód}

1.2.1. Przymus. Zawarcie małżeństwa wymaga wolności w podejmowaniu decyzji i wzajemnej zgody. Miłość i wzajemna zgoda są jedynymi zasadami i niezbędnymi warunkami do zawarcia małżeństwa chrześcijańskiego ${ }^{8}$. W związku z tym wolność wyboru i decyzji jest podstawową przesłanką do ważnego zawarcia małżeństwa. Chrześcijaństwo na mocy swoich podstawowych zasad moralnych i bardzo wzniosłego poglądu na małżeństwo, godność i wolność każdej osoby ludzkiej wymagało i wymaga, aby zawarcie związku małżeńskiego w swojej treści nosiło charakter wzajemnej zgody? .

Kościół prawosławny, zwracając szczególną uwagę na znaczenie wolności przy zawieraniu małżeństwa, wprowadził do obrzędu sakramentalnego pytanie: „Czy masz dobrą chęć, nieprzymuszoną wolę i trwały zamiar pojąć sobie za żonę tę oto (...), którą (którego) obok siebie widzisz?” Kapłan, gdy otrzyma pozytywną odpowiedź od obu stron, rozpoczyna obrzęd zawarcia sakramentalnego małżeństwa. Sakrament udzielony pod presją uważany jest za nieważny (Sobór Powszechny Czwarty: kan. 27; Sobór Powszechny Szósty: kan. 92; św. Bazyli Wielki: kan. 22, 30 $)^{10}$. Zgodnie z postanowieniami Kanonów osoba przymuszająca zaciaga karę ekskomuniki ${ }^{11}$.

1.2.2. Wiek. Wstąpienie w związek małżeński jest bardzo ważnym momentem w życiu człowieka. Powinien on nastąpić po odpowiednim przygotowaniu i gruntownym przemyśleniu przez nupturientów. Pośród warunków wymaganych do tego, aby godnie i ważnie przyjąć sakrament małżeństwa, jest odpowiedni wiek. Jest to warunek wymagany do tego, aby narzeczeni z pełną świadomością i odpowiedzialnością podchodzili do obowiązków wynikających z małżeństwa. Właściwy wiek suponuje, iż kandydaci do małżeństwa mają właściwą dojrzałość fizyczną i psychiczną ${ }^{12}$.

Odpowiedni wiek uwarunkowany jest przed wszystkim stroną fizyczną pragnących zawrzeć małżeństwo, bowiem małżonkowie powinni być zdol-

8 Por. tamże, s. 89.

9 Por. J. Meyendorff, Matżeństwo w prawostawiu..., dz. cyt., s. 57; por. Mt 19, 5. 11-13.

Io Por. S. Hrycuniak, Prawostawne pojmowanie matżenstwa, dz. cyt., s. 90.

II Por. J. Meyendorff, Matżenstwo w prawostawiu..., dz. cyt., s. 57.

I2 Por. S. Hrycuniak, Prawostawne pojmowanie matżeństwa, dz. cyt., s. 91. 
ni do współżycia małżeńskiego. Wiek młodzieńczy i starczy jest przeszkodą do zawarcia małżeństwa ${ }^{13}$.

Od 1830 roku do ważności małżeństwa wymagane jest od mężczyzny ukończenie osiemnastu lat, a od kobiety przynajmniej szesnastu ${ }^{14}$. Przepis ten nie został zniesiony do dziś. W tymże samym zbiorze przepisów znajdujemy normę, która stanowi, iż dla obydwu płci górną granicę wieku dla ważnego zawarcia małżeństwa stanowi ukończony sześćdziesiąty rok życia. Jak pokazuje życie, Kościół wyjątkowo pozwala na zawarcie małżeństwa osobom do osiemdziesiątego roku życia. Po sześćdziesiątym roku życia do ważnego zawarcia małżeństwa wymagana jest dyspensa biskupa. Małżeństwo po osiemdziesiątym roku życia jest wykluczone. Kościół prawosławny nazywa „nieczystością” zawieranie związków małżeńskich, a przede wszystkim obcowanie małżeńskie w wieku starczym ${ }^{15}$.

1.2.3. Pokrewieństwo i powinowactwo. Pokrewieństwo jest to wzajemny stosunek łączący pochodzących od wspólnego przodka. Jest ono oparte na wspólnocie krwi. Krewnymi w linii prostej są osoby pochodzące od siebie przez fakt zrodzenia. Krewnymi w linii bocznej są osoby pochodzące od wspólnego przodka, lecz nie od siebie przez rodzenie. Pokrewieństwo prawne powstaje z przysposobienia (adopcja); między przysposabiającym i przysposobionym powstaje taki stosunek, jak między rodzicem a dzieckiem ${ }^{16}$. Obecnie pokrewieństwo prawne stanowi kanoniczną przeszkodę do zawarcia małżeństwa w tych krajach, w których według prawa państwowego pokrewieństwo wypływające z przysposobienia zabrania zawierania małżeństwa. Jeżeli przysposobienie ustaje według prawa państwowego, wygasa również przeszkoda kanoniczna.

Jeden z prawosławnych teologów abp Sawa odnośnie do omawianej kwestii stwierdza: „Pokrewieństwo w linii prostej wstępnej i zstępnej stanowi bezwzględną przeszkodę do zawarcia małżeństwa. Pokrewieństwo w linii bocznej stanowi bezwzględną przeszkodę do zawarcia małżeństwa do czwar-

13 Por. tamże.

I4 Zob. Zbiór praw, t. X, cz. I, art. 3.

I5 Por. A. Znosko, Prawostawne prawo kościelne, cz. II, Warszawa 1975, s. 65.

r6 Por. P. Gajda, Prawo matżeńskie Kościoła katolickiego, Tarnów 2000, s. 127; por. M. Zaborowski, Przeszkoda pokrewienstwa $w$ rozwoju prawno-historycznym, „Tarnowskie Studia Teologiczne", 2010, t. 29/2, s. 83-104. 
tego stopnia włącznie. Pokrewieństwo wiążące powinowactwem dwa rody stanowi bezwzględną przeszkodę do zawarcia małżeństwa do czwartego stopnia włącznie. Małżeństwo w piątym stopniu jest uzależnione od decyzji biskupa diecezjalnego. Pokrewieństwo wiążące powinowactwem trzy rody stanowi bezwzględną przeszkodę do zawarcia małżeństwa tylko w pierwszym stopniu. Następne stopnie do czwartego włącznie wymagają zezwolenia biskupa diecezjalnego. W pokrewieństwie duchowym ${ }^{17}$ przeszkodę do zawarcia małżeństwa stanowi pokrewieństwo zachodzące pomiędzy rodzicami chrzestnymi a ich chrześniakami oraz pomiędzy rodzicami chrzestnymi a rodzicami ich chrześniaków. Nie ma pokrewieństwa między samymi chrzestnymi oraz między rodzeństwem chrzestnych" ${ }^{18}$.

Przyczyny ograniczenia zawierania małżeństw między krewnymi wynikają z samej natury człowieka. Wskazują na to przesłanki medyczne, które ukazują niekorzystne skutki takich małżeństw. Także ze strony duchowej, etycznej wspomniane związki są nieprawidłowe ${ }^{19}$.

1.2.4. Niezdolność płciowa. Jednym z podstawowych celów małżeństwa sakramentalnego, zgodnie z nauczaniem Kościoła prawosławnego, jest prokreacja oraz zaspokojenie popędu seksualnego. Niezdolność do współżycia małżeńskiego bywa, zdaniem S. Hrycuniaka - jednego z teologów prawosławnych, utajniana i może być ujawniona zazwyczaj dopiero po zawarciu małżeństwa. W swojej istocie uniemożliwia podjęcie współżycia seksualnego, które należy do podstawowych celów małżeństwa. Niemoc płciowa stanowi podstawę do rozwiązania małżeństwa. Jeżeli niezdolność ujawniona została przed zawarciem małżeństwa, stanowi ona bezwzględną przeszkodę do jego zawarcia ${ }^{20}$.

1.2.5. Różność religii. Jedność wiary, tj. włączenie w Kościół prawosławny, stanowi formalny warunek zawarcia małżeństwa sakramentalnego w tej wspólnocie kościelnej ${ }^{21}$.

„Nie jest rzeczą godną, aby mężczyzna prawosławny wstępował w związki małżeńskie z kobietą heretyczką, ani też by niewiasta prawosławna łączyła się z mężczyzną heretykiem. Jeżeli zaś ujawni się, że ktokolwiek tak postąpił,

${ }_{17}$ Por. kan. 811 \$ 1 KKKW.

I8 Sawa Hrycuniak, Prawosławne pojmowanie matżeństwa, dz. cyt., s. 96.

I9 Por. tamże, s. 93-94.

20 Por. tamże, s. 92.

2I Por. J. Meyendorff, Matżeństwo w prawostawiu..., dz. cyt., s. 60. 
należy uważać związek małżeński za niepewny i nieprawne pożycie rozwiązać. Albowiem nie przystoi mieszać to, co jest niezmieszane, ani też łączyć z owcą wilka, a z udziałem Chrystusa los grzeszników. Jeżeli ktokolwiek postanowione przez nas naruszy, niech będzie od nas odłączony"22.

„Jeżeli zaś niektórzy pozostając jeszcze jako niewierzący i nie będąc jeszcze przyłączeni do stada prawosławnego, zawarli między sobą związek małżeński, zaś potem jedno z nich, obrawszy co jest dobre, doszło do światła prawdy, a drugie pozostało $\mathrm{w}$ więzach błędu, niewierząca $\mathrm{z}$ mężem, lub odwrotnie niewierzący mąż z wierzącą małżonką, to wówczas niech się nie rozłączają w myśl słów Apostoła: «Mąż poganin uświęcony jest przez żonę i żona poganka uświęcona jest przez wierzącego męża»"23.

Synody w Laodycei (kan. 10 i 31), w Kartaginie (kan. 21) oraz Synody Ekumeniczne: Czwarty i Szósty (kan. 14 i 72) jednoznacznie zakazywały zawierania małżeństwa między prawosławnymi i nieprawosławnymi ${ }^{24}$.

Obecnie, gdy nawołuje się do „interkomunii”, kwestia zawierania małżeństw „mieszanych” jest łagodniej traktowana. Generalnie rzecz biorąc, małżeństwa „mieszane” są w Kościele prawosławnym zabronione, w praktyce jednak mają miejsce ${ }^{25}$. Zakaz ten ma swoje źródło w pojmowaniu istoty małżeństwa, jako nie tylko powiązania humani, lecz divini iuris communicatio. Kapłan prawosławny nie ma prawa pobłogosławić małżeństwa wyznawcy prawosławnego z nieochrzczonym. Jak uważają prawosławni teologowie, trudno jest wprowadzić do obrządku sakramentu tego, kto nie uznaje Zbawiciela. Jest to, ich zdaniem, profanacja świętości sakramentu ${ }^{26}$.

Jeśli wyznawca prawosławny zawiera małżeństwo poza wspólnotą Kościoła prawosławnego, ten jasno świadczy, że nie jest godny pozostawać wyznawcą „Matki Kościoła”. Błogosławieństwo małżeństwa wyznawcy prawosławnego ze stroną nieprawosławną, udzielone przez kapłana nieprawosławnego, jest nieważne dla strony prawosławnej, dopóki nie zostanie pobłogosławione przez kapłana prawosławnego ${ }^{27}$.

\footnotetext{
${ }_{22}$ Tamże, s. 117; autor powołuje się na Sobór w Trullo, kan. 72.

${ }_{23}$ Tamże; autor powołuje się na Szósty Sobór Ekumeniczny, kan. 72 oraz na Kor 7, 14.

24 Por. A. Znosko, Prawostawne prawo kościelne, dz. cyt., s. 62.

25 Por. Sawa Hrycuniak, Prawostawne pojmowanie matżeństwa, dz. cyt., s. 98.

${ }_{26}$ Por. tamże, s. 101.

27 Por. tamże, s. 51.
} 
1.2.6. Kapłaństwo. Kanony apostolskie nakazywały, aby ci, którzy weszli do duchowieństwa w stanie wolnym, nie zawierali małżeństwa (kan. 26). Zgodnie $\mathrm{z}$ tym postanowieniem wstępujący w stan kapłański w stanie wolnym nie może zawrzeć małżeństwa. Na mocy tego unormowania, ten duchowny, który pomimo tego zawrze małżeństwo, zostanie pozbawiony godności kapłańskiej (Sobór w Neocezarei, kan. 1). Szósty Sobór Ekumeniczny (kan. 6) postanowił, iż ten, kto pragnie zostać duchownym, może zawrzeć małżeństwo, ale musi to uczynić przed przyjęciem święceń (przed diakonatem) ${ }^{28}$.

Prawosławne prawo zabrania, pod rygorem nieważności, małżeństwa z osobami, które przyjęły święcenia wyższe (diakonat, prezbiterat). Nie jest też dozwolone małżeństwo z kałanami rozwiedzionymi czy też owdowiałymi. Kapłan, który łamie te zasady, zostaje pozbawiony swojej funkcji kościelnej. Prawosławni teologowie nie mają jednoznacznej odpowiedzi, czy w takiej sytuacji małżeństwo jest ważne, czy też nie? Wątpliwość taka zrodziła się już na Szóstym Soborze Ekumenicznym ${ }^{29}$.

1.2.7. Stan zakonny. Zgodnie z kościelnymi przepisami prawosławnymi zabrania się mnichom i mniszkom zawierania małżeństwa. Jest to zgodne z tym, co stanowi kanon 18 Kodeksu Bazylego Wielkiego: „to, co zostało poświęcone Bogu, należy do Boga”. Związek małżeński zawarty po naruszeniu ślubu czystości traci swą ważność. Kanon 19 Soboru w Ancyrze naucza: „Ci, którzy ślubowali dziewictwo i ślubu nie dotrzymali, niech podejmą karę «epitemii» ${ }^{30}$ nakładaną na wstępujących w związki małżeńskie po raz drugi”31.

Kościół prawosławny potępia związki osób, które złożyły śluby zakonne, pomimo tego dopuszcza możliwość ich zawarcia i zalegalizowania. W praktyce, jak stwierdza jeden z teologów prawosławnych, błogosławi je, nie narzucając nawet kary „epitemii” na współmałżonków ${ }^{32}$.

1.2.8. Czwarte małżeństwo. Kościół prawosławny w niektórych okolicznościach dopuszcza możliwość rozwiązania małżeństwa przez rozwód i zezwala na kolejne małżeństwo zarówno osobom owdowiałym, jak i rozwiedzionym ${ }^{33}$.

\footnotetext{
${ }_{28}$ Por. J. Meyendorff, Matżeństwo w prawostawiu..., dz. cyt., s. 121.

29 Por. tamże, s. 77-81.

30 Epitemia - niedopuszczenie małżonków do Komunii świętej przez okres jednego roku.

${ }^{\text {I }}$ Cytat za: A. Znosko, Prawostawne prawo kościelne, dz. cyt., s. 63-64.

32 Por. tamże, s. 63-64.

33 Por. tamże, s. 69.
} 
Pomimo tego postuluje bezwzględną wyższość monogamii. Toleruje kolejne małżeństwa ze względu na pobłażliwość dla ludzkiej słabości. Na osoby zawierające kolejne małżeństwa nakładane są surowe pokuty. Kategorycznie wykluczona jest możliwość zawarcia małżeństwa po raz czwarty. „Nikt nie ośmieli się zawrzeć czwartego związku małżeńskiego i jeśli ktoś będzie pragnął żyć jak mąż z żoną, to będzie wyłączony z każdej kościelnej celebracji i będzie mu nawet zabronione wejście do świętej świątyni, tak długo jak będzie przy tym trwał (...)"34.

1.2.9. Inne przeszkody. Wyżej wymienione przeszkody, aczkolwiek podstawowe i najważniejsze w prawosławnym prawie małżeńskim, nie wyczerpują całości zagadnienia. Niestety, prawosławne prawo nie jest, jak dotąd, skodyfikowane. Sporządzenie całościowego, zamkniętego katalogu tych przeszkód, na podstawie starożytnych kanonów, byłoby żmudną pracą. Poza tym wiele z tych starożytnych normatywnych tekstów straciło już swą aktualność. Do innych przeszkód do zawarcia małżeństwa, które są wymieniane w starożytnych kanonach i nie straciły na aktualności, należy zaliczyć: chorobę umysłową, bigamię, błąd, zaręczyny z inną osobą, wdowieństwo po trzecim małżeństwie, karę więzienia, konkubinat, uprowadzenie, okres wdowiej żałoby, brak zaświadczenia o zawarciu małżeństwa cywilnego ${ }^{35}$.

Ks. Aleksy Znosko nie omawia tych wyżej wymienionych przeszkód, poprzestaje tylko na ich wyliczeniu. Wynika to być może z tego, iż Kościół prawosławny przygotowuje się do soboru. Specjalna Komisja Przygotowawcza sporządziła wykaz propozycji dotyczących właśnie przeszkód małżeńskich. Propozycje te zostały opracowane w następującym brzmieniu:

1. „Zaproponować, aby w dziedzinie stopni pokrewieństwa stosować szeroką ekonomię, tak by respektować podstawowe wymagania biologiczne i socjologiczne oraz nie wchodzić w kolizję z prawem państwowym danego kraju;

2. Również stosować ekonomię w przypadku sukcesywnych małżeństw przy jednoczesnym, mocnym podkreśleniu ideału chrześcijańskiej monogamii;

3. W duchu zrozumienia ekumenicznego, przy równoczesnym uwzględnieniu lokalnych warunków międzynarodowych, dopuścić śluby mieszane ze wszystkimi ochrzczonymi;

34 J. Meyendorff, Matżenstwo w prawostawiu..., dz. cyt., s. 118.

35 Por. A. Znosko, Prawostawne prawo kościelne, dz. cyt., s. 69-70. 
4. Zastanowić się nad możliwością jednostronnego błogosławieństwa w wypadku, gdy jedna strona jest niewierząca;

5. Znieść terminy ograniczające zawieranie małżeństw poza dawnymi terminami czterech postów" 36 .

Postulaty te, zwłaszcza trzy ostatnie, są bardzo postępowe i wskazują na ducha ekumenicznego w Kościele prawosławnym.

\subsection{Okresowe terminy zakazujące zawierania małżeństwa}

Ograniczeń dotyczących dni, kiedy w Kościele prawosławnym nie można zawierać małżeństwa, jest wiele. Większość z wydanych rozporządzeń w tej materii jest niejednolita. Dodatkowym utrudnieniem jest także to, że nie są one nigdzie spisane i usystematyzowane. W prawosławiu przyjmuje się, że małżeństwa nie można zawierać:

1. w okresie Wielkiego Postu;

2. od niedzieli mięsopustnej do niedzieli o Apostole Tomaszu (pierwsza niedziela po Zmartwychwstaniu);

3. od pierwszej niedzieli po święcie Zesłania Świętego Ducha (Wszystkich Świętych) do 29 czerwca;

4. od święta Bożego Narodzenia (25 grudnia) do 6 stycznia;

5. w przededniu niedziel i wielkich świąt;

6. w przededniu święta patronów świątyni parafialnej i odpustów;

7. w przededniu 1 października, 29 sierpnia, 14 września, a także 26 września i 9 maja $^{37}$.

Zapewne ograniczenia te umotywowane są troską o to, by nie łączyć zawierania małżeństwa z wyżej wymienionymi świętami, tzn. aby jedne nie przesłaniały drugich. Ponadto prawosławie zabrania zawierania małżeństwa w konkretne dni tygodnia, czy nawet pory dnia. We wtorki, czwartki i soboty mogą być błogosławione związki małżeńskie do momentu rozpoczęcia nieszporów w danej parafii - tak uważa abp Sawa ${ }^{38}$.

Obecna praktyka w prawosławiu jest niejednolita. Prawosławne Kościoły bałkańskie nie błogosławią małżeństw w środy i piątki przez cały dzień,

${ }_{36}$ Tamże, s. 71.

37 Zob. S. Hrycuniak, Prawostawne pojmowanie matżeństwa, dz. cyt., s. 105.

$3^{8}$ Por. tamże, s. 108. 
natomiast dopuszczają taką możliwość w przeddzień tych dni, tj. we wtorki i czwartki. Praktyka Kościoła rosyjskiego i Kościoła prawosławnego w Polsce jest nieco inna. Kościoły te opierają się na 90 kanonie Szóstego Soboru Powszechnego, który stwierdza, że dzień zaczyna się po odprawieniu nieszporów (wieczerni) w przededniu danego dnia. Kończy się nieszporami tego dnia. W związku z tym w tych Kościołach sprawowany jest sakrament małżeństwa w środy i piątki po południu. Nie błogosławi się małżeństw we wtorki i w czwartki ${ }^{39}$. Prawosławni teologowie twierdzą, że jest to możliwe, ponieważ nie posiadają oni autorytatywnego kanonicznego dokumentu źródłowego podającego wszystkie dni, w które zabronione jest błogosławienie małżeństw ${ }^{40}$.

\section{Rozwód w prawosławiu}

\subsection{Uzasadnienie teologiczne}

Prawosławne rozumienie zagadnienia rozwodu opiera się na następujących założeniach:

Małżeństwo jest sakramentem udzielonym dwojgu ludziom w Ciele Kościoła przez kapłańskie błogosławieństwo. Jak każdy sakrament, odnosi się do życia wiecznego w Królestwie Bożym i z tego względu nie może być rozwiązane przez śmierć jednego z małżonków, lecz stwarza pomiędzy nimi - jeśli tego pragną z całą powagą i ,jeśli jest im to dane” ${ }^{41}$ - wieczną więz $z^{42}$.

Małżeństwo jako sakrament nie jest magicznym aktem, lecz darem łaski. Małżonkowie mogli popełnić błąd, prosząc o łaskę małżeństwa, gdy nie byli jeszcze przygotowani na jej przyjęcie, czy też mogą okazać się niezdolnymi uczynienia tej łaski owocną. W tych przypadkach Kościół może uznać fakt, iż łaska nie została „przyjęta” i zezwolić na powtórne małżeństwo. Nigdy jednak nie zachęca do powtórnego małżeństwa - nawet w przypadku osób owdowiałych, ze względu na wieczny charakter więzi sakramentalnej małżeństwa. Co najwyżej je toleruje w konkretnych przypadkach, gdy wydaje się to być najlepszym rozwiązaniem dla każdego człowieka. Kościół nigdy nie „uznał”

\footnotetext{
39 Por. tamże.

40 Por. tamże, s. 109.

${ }_{4 \mathrm{I}}$ Mt 19, 11.

${ }_{42}$ Por. J. Meyendorff, Matżeństwo w prawostawiu..., dz. cyt., s. 64-65.
} 
rozwodu. Rozwód był uważany w prawosławiu za ciężki grzech, ale Kościół wyszedł naprzeciw człowieka, grzesznika i dał mu „nową szansę”. Wcześniej tenże grzesznik musi okazać skruchę $e^{43}$. Sakrament małżeństwa, według teologów prawosławnych, nie jest nieodwołalną formułą prawną o racjonalistycznym podłożu, lecz przeciwnie, stanowi dynamiczną możliwość osobowego przyjęcia i dowartościowania łaski danej od Boga. Z tego względu, gdy małżonkowie nie skorzystali twórczo z przekazanej im łaski, a ich małżeństwo przestało być więzią (communio) międzyosobową, istnieje możliwość, jaką daje im Kościół, poszukiwania nowej miłosnej więzi. Kościół w takiej sytuacji okazuje się łaskawy, uznaje ich niepowodzenie i daje możliwość zawarcia nowego związku małżeńskiego ${ }^{44}$.

\subsection{Okoliczności dopuszczające rozwód}

Klasycznym przykładem rozwiązania ważnie zawartego małżeństwa we wszystkich Kościołach prawosławnych jest cudzołóstwo (alduterium) któregoś z małżonków. Jedynie z tej przyczyny rozwód jest w pełni usprawiedliwiony. Kościół prawosławny bazuje w tej materii na tekstach Nowego Testamentu, starożytnych kanonach i nauce ojców Kościoła (Bazyli Wielki: kan. 77; Tymoteusz Aleksandryjski: kan. 15, 87; Sobór w Trullo, kan. 87). W przypadku, gdy monogamiczne małżeństwo zostało zniszczone przez grzech cudzołóstwa, rozwód bez ponownego małżeństwa był uważany za normę dla chrześcijan ${ }^{45}$.

„Każdy, kto oddala swą żonę - poza wypadkiem nierządu naraża ją na cudzołóstwo" ${ }^{4}$. Jest to główne uzasadnienie praktyki rozwodowej w Kościele prawosławnym. Poza zdradą małżeńską tenże Kościół przyjmuje jeszcze inne powody do orzeczenia rozwodu ${ }^{47}$. Powody te bywają różne w różnych krajach, bowiem często Kościół prawosławny sugeruje się w tym względzie przepisami

43 Por. tamże, s. 68.

44 Por. Ch. Jannaras, Matżeństwo jako sakrament objawienia się prawdy osoby $w$ tradycji prawostawnej, „Communio”, R. 6, 1986, nr 6 (36), s. 36-45.

45 Por. J. Ericson, Orthodox perspectives on divorce and remarriage, [w:] The challenge of our past, Studies in orthodox canon law and Church history, Crestwood 1991, s. 44.

${ }_{46}$ Mt 5, 32.

47 Por. P. Pałka, Niektóre problemy prawne związane z zawieraniem matżeństw przez katolików z prawostawnymi, „Częstochowskie Studia Teologiczne”, 1997, t. 5, s. 241. 
państwowymi. Kościół prawosławny w Polsce poza zdradą małżeńską uznaje następujące powody do uzyskania rozwodu:

1. odpadnięcie małżonka od prawosławia;

2. skazanie współmałżonka na ciężkie więzienie na czas nie krótszy niż trzy lata z pozbawieniem praw obywatelskich;

3. zaraźliwa choroba weneryczna;

4. choroba trądu;

5. nastawanie na życie i zdrowie współmałżonka lub jego dzieci;

6. nieobecność współmałżonka niedającego o sobie znaku życia przynajmniej przez trzy lata, a w czasie wojny przez dwa lata;

7. ciężka nieuleczalna choroba psychiczna uniemożliwiająca współżycie małżeńskie;

8. zawarcie przez jednego z małżonków nowego związku małżeńskiego, gdy pierwszy związek nie został jeszcze prawnie rozwiązany;

9. złośliwe opuszczenie małżonka;

10. faktyczny rozkład pożycia małżeńskiego;

11. niezgodność charakterów małżonków uniemożliwiająca realizowanie współżycia małżeńskiego;

12. niezdolność do współżycia małżeńskiego zaistniała przed ślubem nie z racji podeszłego wieku, a powstała po ślubie wtedy, gdy została spowodowana przez samego małżonka;

13. wstąienie jednego małżonka do klasztoru ${ }^{48}$.

Wyżej wymienione przyczyny rozwodu nie stanowią katalogu zamkniętego. Uznanie ich przez Kościół prawosławny jest wynikiem stosowania przezeń tzw. ekonomii (tj. łagodnego tłumaczenia przepisów o trwałości związku małżeńskiego). Ostatnie z wymienionych przyczyn odzwierciedlają inspirację prawem państwowym ${ }^{49}$.

Prawosławny metropolita obu Ameryk Jakovos w czerwcu 1966 roku wygłosił deklarację pod tytułem „Węzeł małżeński powinien być zacieśniony”. Przypominając, że w przeszłości trybunały prawosławne dość często udzielały rozwodów małżeństwom, które już wcześniej uzyskały rozwód cywilny, zazna-

$4^{8}$ Zob. A. Znosko, Prawostawne prawo kościelne, dz. cyt., s. 69-70.

49 Zob. Kodeks rodzinny i opiekuńczy, Dz. U. z 1964, Nr 9, poz. 59 z 1975, Nr 75 , poz. 234 z 1986, Nr 36, poz. 180 z 1990, Nr 34, poz. 198 z 1995, Nr 83, poz. 417 z 1998, Nr 117, poz. 757 z 1999. 
czył, iż taki sposób postępowania nie był „zdrowy dla społeczeństwa prawosławnego" i że stanowił ponadto przeszkodę w rozmowach z Rzymem na temat zjednoczenia ${ }^{50}$. Z tego też powodu metropolita zasugerował powołanie komisji, która zajęłaby się opracowaniem zamkniętego katalogu powodów, z jakich, ewentualnie, byłyby udzielane rozwody.

\subsection{Forma prawna rozwodu}

Mówiąc o formie prawnej rozwodu, należy odróżnić rozwód właściwy od orzeczenia nieważności małżeństwa na skutek przeszkody zrywającej. Rozwód dokonuje się na prośbę jednego z małżonków na mocy wyroku Sądu Eparchialnego, w składzie kolegialnym, zatwierdzonego zawsze przez hierarchę miejsca, a tylko w razie apelacji od tego wyroku również przez świątobliwy Synod, spełniający w tym wypadku rolę drugiej i ostatecznej instancjii ${ }^{51}$ Prawosławne prawodawstwo kanoniczne uznaje dwie instancje sądu kościelnego, które sprawują zarazem zarząd tym Kościołem ${ }^{52}$. Wyrok rozwodowy jest podstawą do zawarcia kolejnego związku małżeńskiego. W Kościele prawosławnym dopuszcza się trzykrotne zawieranie małżeństwa.

\section{Zakończenie}

Jak widzimy, na podstawie przeprowadzonej analizy, ujęcie małżeństwa w prawodawstwie Kościoła prawosławnego ukazuje różnice w podejściu do tej instytucji w porównaniu do tego, co mówi na temat tej instytucji prawnej katolicki Kodeks prawa kanonicznego. Co do warunków do zawarcia małżeństwa (formalności, przeszkody), należy stwierdzić, iż dostrzegamy tutaj pewne podobieństwa, ale i różnice. Wynikają one przed wszystkim z różnej tradycji kulturowej i zaszłości historycznych. Najważniejszą różnicą w tychże dwóch systemach prawnych jest kwestia rozwodu. Jak wynika z powyższych rozważań, Kościół prawosławny dopuszcza możliwość rozwodu w pewnych szczególnych sytuacjach, praktyka ta jest obca prawodawstwu katolickiemu,

5o Por. O. Rousseau, Rozwód i ponowny zwiąek matżeński na Wschodzie i na Zachodzie, „Concilium”, R. 2-3, 1969, s. 180.

5I Por. P. Pałka, Niektóre problemy prawne..., dz. cyt. s. 243.

52 Por. A. Znosko, Prawostawne prawo kościelne, dz. cyt., s. 47. 
które nie daje takiej możliwości, gdyż w ocenie tego Kościoła małżeństwo jest nierozerwalne. W obydwu systemach prawnych istnieje możliwość przeprowadzenia procesu w celu stwierdzenia nieważności małżeństwa.

\section{Marriage and Divorce in the Orthodox Church - a Legal and Canonical Aspect}

Summary

The study above shows briefly legal issues related to marriage in the Orthodox Church. It takes notes of fundamental differences regarding a sacramental marriage in the Latin and Orthodox Churches. The study is divided into two chapters separated into particular points.

The first chapter discusses legal conditions to marry, i.e. marriage formalities and main obstacles. The second one approaches us to a divorce issue in the Orthodox church: its form and circumstances. The analysis of the issues mentioned above is to show differences and similarities between marriage-related legislation in both Christian Churches.

Keywords: marriage, divorce, legal conditions to marry, the Orthodox Church, Christianity 
